\title{
Kompetensi Kepribadian Guru Pendidikan Agama Kristen Dalam Meningkatkan Kecerdasan Spiritual Peserta Didik Ditingkat Sekolah Menengah Pertama
}

\author{
Imayanti Nainggolan *, Ferdinandes Petrus Bunthu ${ }^{2}$, Dewi Lidya $\mathrm{S}^{3}$, Desetina Harefa ${ }^{4}$, \\ Haposan Simanjuntak ${ }^{5}$, Ester Lina Situmorang ${ }^{6}$ \\ 1,2,3,4,5, 6 Prodi PAK, STT Real Batam \\ imayantinaingg22@gmail.com
}

\begin{abstract}
This study departs from the author's observations of the potential for worsening moral decadence among students in several junior high schools. In the author's observation, the author pays attention to the need for PAK teacher competencies to anticipate the potential for spiritual poverty. This study aims to find out and provide solutions to each student's problems at the junior high school level with the ability of teachers known as PAK teacher personality competencies. This research uses descriptive qualitative method. The results of this study indicate that the teacher is the bridge and at the same time the spearhead who brings change in the regeneration of the formation of a whole person in schools.
\end{abstract}

Keywords: Teacher Competence, Spiritual Intelligence

\begin{abstract}
Abstrak
Tuhan Penelitian ini berangkat dari pengamatan penulis terhadap potensi dekadensi moral yang memburuk di kalangan peserta didik di beberapa sekolah menengah pertama. Dalam pengamatan penulis Penulis memperhatikan diperlukannya kompetensi guru PAK untuk mengantisipasi maraknya potensi kemiskinan spiritual. Penelitian ini bertujuan untuk mengetahui dan memberi solusi dari setiap permasalahan peserta didik ditingkat Sekolah Menengah Pertama dengan kemampuan guru yang dikenal dengan Kompetensi kepribadian guru PAK. Penelitian ini menggunakan metode kualitatif deskrptif. Hasil penelitian ini menunjukkan bahwa guru merupakan jembatan dan sekaligus ujung tombak yang membawa perubahan dalam regenerasi pembentukan manusia seutuhnya di sekolah.

Kata kunci: Kompetensi Guru, Kecerdasaran Spritual
\end{abstract}




\section{PENDAHULUAN}

Sebagai seorang guru yang adalah ujung tombak dari pendidikan, harus mampu membuat peserta didik aktif mengembangkan potensi dirinya untuk memiliki kekuatan spiritual keagamaan, pengendalian diri, kepribadian, kecerdasan akhlak mulia serta keterampilan yang diperlukan dirinya, masyarakat, bangsa dan negara. Seorang pendidik harus mampu membantu peserta didik dalam mengembangkan potensi yang dimilikinya dan ikut berperan dalam meningkatkan keimanan dan membentuk kepribadian peserta didik, baik secara lahir dan batin supaya tercipta didalam diri peserta didik tersebut kecerdasan yang diterima dari guru atau pendidiknya. Pendidikan untuk mencerdaskan kehidupan bangsa dan mengembangkan manusia Indonesia seutuhnya, manusia yang beriman, berbudi pekerti luhur, dan memiliki pengetahuan dan keterampilan kesehatan jasmani dan rohani, kepribadian yang mantap serta rasa tanggung jawab bermasyarakat dan bernegara, memiliki peranan penting untuk memelihara eksistensi setiap bangsa didunia sepanjang zaman, untuk itu perwujudan masyarakat yang berkualitas dan bermoral sudah menjadi tanggungjawab guru. Maka dari itu guru sebagai sosok yang digugu dan ditiru oleh peserta didik, harus memiliki kepribadian yang mantap untuk dicontoh oleh peserta didiknya dalam mempersiapkan sosok individu yang berakhlak, berpengetahuan dan bermartabat, seperti ditegaskan dalam rumusan tujuan pendidikan nasional yang tertuang dalam UU No.20 tahun 2003 tentang sistem pendidikan nasional bertujuan untuk mengembangkan peserta didik agar menjadi manusia yang beriman dan bertaqwa kepada Tuhan Yang Maha Esa, berakhlak mulia, sehat, berilmu, cakap, kreatif, mandiri, dan menjadi warga negara yang demokratis dan bertanggungjawab

Dalam dunia pendidikan, gagalnya pendidikan disebabkan gagalnya institusi pendidikan dalam mendidik moral dan menciptakan kepribadian peserta didik yang baik. Berdasarkan hal-hal tersebutlah maka penelitian ini menganggap penting bahwa dimensi spiritual untuk dikaitkan dengan pendidikan, khususnya dalam proses meningkatkan akhlak peserta didik yang sudah dimilikinya. Peserta didik yang bermoral dan berakhlak harus dibina dari nilai spiritualnya, karena hanya takut akan Tuhanlah menjadikan mereka memiliki nilai kecerdasan spiritual yang mantap. Sesuai dengan uraian latar belakang diatas, maka penelitian tentang pokok persoalan kecerdasan spiritual peserta didik ditingkat sekolah menengah pertama sangat penting dilakukan guna untuk menangani permasalahan-permasalahan yang muncul dari hal tersebut melalui kompetensi kepribadian guru Pendidikan Agama Kristen. 


\section{METODE}

Penelitian ini dilakukan oleh penulis dengan mengunakan metode analisis data kualitatif. Pendekatan yang dilakukan dengan menggunakan wawancara dan observasi dengan menjawab pertanyaan seperti apa, mengapa atau bagaimana kondisi kecerdasan spiritual peserta didik di sekolah menengah pertama pada umumnya dan bagaimana bagaimana kompetensi kepribadian guru PAK menjawab persoalan kemiskinan spiritual peserta didik ditingkat Sekolah Menengah.

\section{HASIL DAN PEMBAHASAN}

\section{Hakekat kecerdasan Spritual}

\section{Kecerdasan Spiritual}

Pengertian kecerdasan spiritual adalah kemampuan jiwa dan hati yang dimiliki seseorang untuk membangun dirinya dengan maksimal melalui berbagai kegiatan positif sehingga mampu menyelesaikan berbagai persoalan dengan melihat makna yang terkandung didalamnya. ${ }^{1}$ Orang yang memiliki kecerdasan spiritual akan mampu menyelesaikan permasalahan yang dihadapinya dengan melihat permasalahan itu dari sisi positifnya sehingga permasalahan dapat diselesaikan dengan baik dan cenderung melihat suatu masalah dari maknanya. Kemampuan untuk bisa memahami makna yang terjadi di lingkungan sehingga bisa memiliki fleksibilitas untuk menghadapi persoalan yang ada juga bagian dari kecerdasan spiritual. Kecerdasan spiritual menjadikan kita dapat menempatkan perilaku dan tindakan serta hidup ke dalam makna yang lebih luas, hal itulah yang akan menilai setiap tindakan ataupun jalan hidup dari seseorang apakah lebih bermakna dibandingkan dengan yang lainnya.

\section{Karakteristik Kecerdasan Spiritual}

\section{Kesadaran Yang Tinggi}

Memiliki kesadaran akan diri sendiri, orang lain bahkan lingkungan sekitar merupakan hal yang penting dan menjadi dasar yang mampu meningkatkan kehidupan kita. Dalam perjalanan kehidupannya, seorang peserta didik pasti akan menemukan tantangan seperti menghadapi lingkungan yang kacau, kebuntuan dalam berpikir atau bahkan memiliki hubungan yang tidak baik dengan teman-temannya. Dengan kesadaran inilah, dapat membuatnya melewati setiap tantangan dengan baik. Orang yang memiliki kesadaran akan diri dan lingkungan akan memiliki mental yang kuat dan mampu menarik diri dari keramaian.

\footnotetext{
${ }^{1}$ Prima Vidya Asteria, Membangun Kecerdasan Spiritual Anak Melalui Pembelajaran Membaca Sastra (Malang: UB Press, 2014). 21-22
} 


\section{Kerendahan Hati}

Orang yang memiliki sifat baik hati, suka menolong dan juga peduli terhadap sesamanya merupakan cerminan dari kerendahan hati. Dikatakan rendah hati biasanya merujuk pada sifat seseorang. Rendah hati berlawanan dengan besar kepala yang memiliki arti angkuh dan sombong. Seorang yang memiliki sifat rendah hati sudah tentu juga mau melayani keluhan orang lain, memandang setiap orang itu sama, mau mendengar dan menerima kritikan, suka mengalah, lemah lembut dan terkadang mengutamakan kepentingan orang lain dibandingkan kepentingan pribadinya sendiri.

\section{Memiliki Keberanian}

Dikatakan memiliki keberanian bukan saja hanya sekedar kehilangan rasa takut, akan tetapi dapat berdiri dan menyuarakan pendapat bahkan duduk diam untuk mendengar. Mengalami rasa takut adalah hal yang wajar, namun jika tidak berani mengambil resiko maka tidak akan mengalami kemajuan di dalam hidup ini. ${ }^{2}$

Keberanianlah yang membuat seseorang untuk mampu dan bertahan. Jika tidak memiliki keberanian, maka akan takut menghadapi tantangan perubahan zaman. Keberanian untuk menghadapi keadaan apa pun dalam hidup menjadi sebuah modal utama dalam meraih sukses sehingga bisa menghadapi perubahan kehidupan dengan sebaik-baiknya.

\section{Indikator Kecerdasan Spiritual Untuk Sekolah Menengah Pertama}

Anak remaja yang memiliki peningkatan yang baik dalam kecerdasan spiritualnya dapat terlihat dari karakteristik yang dimiliki minimalnya seperti:

\section{Taat Beribadah}

Ketaatan sesorang kepada agamanya terlihat dari ketaatan beribadahnya dan hal itulah yang menjadi tolak ukur yang cukup penting untuk melihat peningkatan kecerdasan spiritual dari seseorang. Agama mengajarkan agar berbuat kebaikan kepada semua orang, saling membantu dan peduli, saling menghormati, tidak mencuri, dan lain sebagainya. Jika hal ini diterapkan dalam kegiatan yang ada di masyarakat maka tentunya seseorang tersebut akan dianggap sebagai orang baik di mata masyarakat lainnya. Taat beribadah, aktif dalam pelayanan serta tertanam didalam sebuah gereja menjadi dasar bagi seorang remaja untuk meningkatkan kecerdasan spiritual yang sudah dimilikinya tersebut sejak dari kecil. Seseorang yang mengalami

2 Tasha Rube, "Cara Memiliki Keberanian," WikiHow. 
peningkatan dalam kecerdasan spiritualnya, sudah pasti paling minimal dia akan taat dalam beribadah. ${ }^{3}$

\section{Jujur dan Bertanggung Jawab}

Seseorang yang memiliki nilai kejujuran dan tanggung jawab dalam dirinya sama seperti memiliki harta yang berharga. Banyak yang beranggapan bahwa menjadi seorang yang jujur pada zaman sekarang tidak keren, karena harus hidup apa adanya. Akan tetapi orang yang mengalami kedewasaan atau peningkatan dalam nilai spiritualnya pasti akan bersikap jujur dan apa adanya serta bertanggung jawab atas setiap perkataan dan perilakunya. Kejujuran dan rasa tanggung jawab sifatnya bukan tetap. Mengapa? Karena perbuatan, tingkah laku serta niat manusia selalu berubah-ubah. Seringkali pada satu masa, menjadi seorang yang jujur dan bertanggung jawab, pada masa lain pula menjadi sebaliknya

\section{Memiliki Sopan Santun}

Dalam menjalani kehidupan sehari-hari kita akan menjumpai banyak orang dan berbagai sifat. Jika bertemu dengan orang yang responnya baik maka sudah tentu kita juga baik dan sopan, akan tetapi terkadang kita bertemu dengan orang yang cetus atau menyebalkan, dalam situasi inilah kita terkadang salah respon dan terkadang hilang kendali. Dikatan sopan santun berarti bagaimana sikap, respon dan perkataan seseorang terhadap apa yang ia lihat, rasakan, dalam situasi dan kondisi apapun.

\section{Disiplin}

Disiplin adalah rasa taat dan patuh terhadap nilai yang dipercata dan menjadi tanggung jawabnya. Dengan kata lain disiplin adalah patuh terhadap peraturan atau tunduk pada pengawasan dan pengendalian. Sikap disiplin yaitu selalu tepat janji, sehingga orang lain percaya karena mendapat kepercayaan dari orang lain.

\section{Kompetensi Kepribadian Guru Pendidikan Agama Kristen}

Seorang guru dapat dikatakan sebagai pendidik profesional apabila mengembangkan kompetensinya dalam mengajar, karena perubahanperubahan yang begitu cepat sering sekali terjadi dalam lingkungan masyarakat yang berdampak kepada dunia pendidikan. Seorang guru tidak

\footnotetext{
${ }^{3}$ Dwi Hastuti, Model Harmonisasi Peran Keluarga Membentuk Karakter Anak
} (Bogor: TP, 2014). 206 
boleh berhenti untuk menggali, mengembangkan, kompetensi yang dimiliki terkhususnya kompetensi kepribadiannya yang terlihat dari tingkah laku dan perbuatannya sehari-hari, sehingga guru bukan hanya mentransfer ilmu tetapi guru juga mentransferkan nilai-nilai kebaikan, nilai-nilai Agama atau nilainilai Iman dan hal itulah yang meningkatkan kecerdasan spiritual yang dimiliki peserta didiknya.

\section{Memiliki Kepribadian Yang Mantap, Stabil}

Menjadi seseorang guru haruslah memiliki kepribadian yang mantap, stabil karena banyak masalah pendidikan yang disebabkan oleh faktor kepribadian guru yang kurang mantap dan kurang stabil. Kepribadian yang mantap dari sosok seorang guru akan memberikan teladan yang baik terhadap anak didik maupun masyarakatnya, sehingga guru akan tampil sebagai sosok yang patut "digugu" (ditaati nasehatnya,ucapannya dan perintahnya) dan "ditiru" (dicontoh sikap dan perilakunya). Oleh sebab itu, sebagai seorang guru, seharusnya kita:

a. Bertindak sesuai dengan norma hukum, sosial, Agama dan Kebudayaan Nasional Indonesia

b. Etos kerja, memiliki rasa tanggung jawab yang tinggi, dan rasa bangga menjadi guru

c. Memiliki konsistensi dalam bertindak sesuai dengan norma

d. menunjukkan pribadi yang dewasa dan teladan

Dalam hal inilah, terlihat kepribadian seorang guru itulah yang akan menentukan apakah ia menjadi pendidik dan pembina yang baik bagi anak didiknya, ataukah akan menjadi perusak atau penghancur bagi masa depan anak didiknya terutama bagi mereka yang sedang mengalami kegoncangan jiwa (tingkat menengah). ${ }^{4}$

\section{Memiliki Kepribadian yang Dewasa}

Sebagai seorang guru harus memiliki kepribadian yang dewasa karena terkadang banyak masalah pendidikan yang muncul yang disebabkan oleh kurang dewasanya seorang guru. Kondisi kepribadian yang demikian sering membuat guru melakukan tindakan - tindakan yang tidak profesional, tidak terpuji, bahkan tindakan - tindakan tidak senonoh yang merusak citra dan martabat keguruan. Tantangan yang cukup berat bagi guru dalam hal kepribadian ini, seperti rangsangan yang sering memancing emosi. Kestabilan

${ }^{4}$ Antonius, Buku Pedoman Guru (Bandung: Yrama Widya, 2014). 
emosi sangat diperlukan, namun tidak semua orang mampu menahan emosi terhadap rangsangan yang menyinggung perasaan. Sehingga, sebagai seorang guru, harus mampu :

a. Menampilkan kemandirian dalam bertindak sebagai pendidik, dimana kepribadiannya akan turut menetukan apakah para guru dapat disebut sebagai pendidik yang baik atau sebaliknya, justru menjadi perusak anak didiknya. Sikap dan citra negatif seorang guru dan berbagai penyebabnya seharusnya dihindari jauh-jauh agar tidak mencemarkan nama baik guru.

b. Memiliki etos kerja sebagai guru, seperti dalam mengawali atau mengakhir pembelajaran dengan tepat waktu

\section{Memiliki Kepribadian Yang Berwibawa}

Dikatakan berwibawa berarti seorang guru harus memiliki perilaku yang berpengaruh positif terhadap peserta didik, ${ }^{5}$ guru harus selalu berusaha memilih dan melakukan perbuatan yang positif agar dapat mengangkat citra baik dan kewibawaannya, terutama di depan peserta didiknya. Selain itu guru juga harus mengimplementasikan nilai-nilai tinggi terutama yang diambilkan dari ajaran agama, misalnya jujur dalam perbuatan dan perkataan, tidak munafik. Apabila sekali saja guru didapati berbohong, apalagi langsung kepada peserta didiknya, niscaya hal tersebut akan menghancurkan nama baik dan kewibawaan sang guru, yang pada gilirannya akan berakibat fatal dalam melanjutkan tugas proses belajar mengajar.

\section{Mampu Mengembangkan Diri}

Di antara sifat yang harus dimiliki guru ialah pembelajar yang baik atau pembelajar mandiri, yaitu semangat yang besar untuk menuntut ilmu. Sebagai contoh kecil yaitu kegemarannya membaca dan berlatih keterampilan yang dapat menunjang dan meningkatkan profesinya sebagai pendidik. Berkembang dan bertumbuh hanya dapat terjadi jika guru mampu konsisten sebagai pembelajar mandiri, yang cerdas memanfaatkan fasilitas pendidikan yang ada di sekolah dan lingkungannya. ${ }^{6}$

\footnotetext{
${ }^{5}$ Muhammad Nurtanto, "MENGEMBANGKAN KOMPETENSI PROFESIONALISME GURU DALAM MENYIAPKAN PEMBELAJARAN YANG BERMUTU," in Inovasi Pembelajaran Berbasis Karakter Dalam Menghadapi Masyarakat Ekonomi ASEAN, 2016. 558

${ }^{6}$ E Mulyasa, Standar Kompetensi Dan Sertifikasi Guru (Bandung: Remaja Rosdakarya, 2007). 34
} 


\section{Kompetensi Kepribadian Guru PAK Dalam Meningkatkan Kecerdasan Spiritual Peserta Didik}

Adapun kompetensi kepribadian guru akan tampak pada sebuah kepribadian yang diwujudkan dalam bentuk mengimani adanya Tuhan melalui ciptaannya serta kompetensi ini dapat menghargai diri sendiri, orang lain dan lingkungan sebagai bentuk syukur kepada Tuhan. Kompetensi tersebut diwujudkan dalam bentuk mempercayai adanya Tuhan melalui ciptaan-Nya dimaksudkan agar guru memiliki pengetahuan, pemahaman, pengalaman dan sikap terhadap sifat Tuhan sebagai pencipta, sekaligus mampu mengenalkan berbagai bentuk ciptaan Tuhan sehingga melahirkan rasa syukur dan takjub yang termanifestasi dalam bentuk perbuatan beribadah sehari-hari. Kompetensi ini dapat dikatakan sebagai kompetensi kepribadian rohani guru.

\section{Guru PAK Menjadi Teladan}

Menjadi seorang guru Agama selain mengajarkan tentang kebenaran kebenaran Firman, guru PAK harus menjadi teladan dari setiap segi kehidupannya. ${ }^{7}$ Kepribadian yang dimiliki guru PAK harus mampu menunjukkan kualitasnya sebagai guru yang menjadi teladan baik perkataan, karakter bahkan kesehariannya. Para peserta didik yang diajari akan secara langsung meniru dan mengikuti setiap apa yang dilihatnya dari gurunya, apalagi di usia tingkat sekolah menengah pertama, mereka juga tidak sungkansungkan untuk mengejek jika gurunya berbuat yang tidak pantas. Jadi sebagai seorang.

\section{Guru PAK menjadi Pemberi Solusi.}

Guru PAK berperan sebagi pengarah atau pemberi solusi harus mempunyai persiapan diri dengan baik, selain pendidikan teologi. Ini berarti ia harus mempunyai kepekaan yang tinggi, artinya dengan hanya berada di dekat konseli atau sedikit berbicara dengannya, atau melihat perubahan sikap ataupun raut wajah, dan lain-lain, guru sudah tahu bahwa muridnya mempunyai pergumulan dan permasalah tertentu dalam dirinya. Selajutnya mempunyai pamahaman awal mengenai pribadi peserta didiknya, dengan cara mencari informasi sebanyak-banyaknya, misalnya, keadaan keluarga, jumlah saudara, pendidikan dan usaha orang tua, tempat tinggal dan lainnya.

\section{Guru PAK menjadi Mentor Dan Pembimbing Rohani}

${ }^{7}$ Talizaro Tafonao, "Peran Guru Agama Kristen Dalam Membangun Karakter Siswa Di Era Digital," BIJAK 2, no. 1 (2018): 1-214. 11 
Guru Pendidikan Agama Kristen sebagai mentor, mempunyai tugas sangat penting, bukan hanya mengajarkan materi pelajaran, tetapi juga mengajarkan hidup, melalui menjadi sahabat yang baik bagi murid-murid. ${ }^{8}$ Hal ini sangat penting, karena murid akan belajar nilai hidup yang benar dari Guru Kristen yang memiliki hati gembala sekaligus adalah mentor dan sahabat murid-muridnya. Sebagai mentor, guru Kristen harus konsisten dalam tanggung jawab dan berdedikasi dalam segala hal yang dilakukan, termasuk di saat yang sulit dan beresiko. Peserta didik pastinya selalu melihat teladan hidup yang indah dari guru Kristen yang mempunyai nilai hidup yang baik. Guru Kristen sebagai mentor, menolong murid-murid untuk melihat dan belajar, betapa berharganya hidup memenuhipanggilan.

Mereka menjadi saksi dan mengalami secara nyata bagaimana ketulusan dan kedalaman dedikasi guru Kristen ketika melayani, mengajar, mendidik dan mendisiplin mereka. Pengalaman bersama guru Kristen sebagai mentor, dapat menolong murid- murid percaya betapa berharganya Tuhan Yesus dalam hidup. Mereka akan meneladani dan memandang persahabatan dengan Tuhan Yesus adalah pilihan yang berharga. Salah satu misi guru Kristen sebagai mentor, adalah mewariskan komitmen nilai abadi yakni, bahwa mengenal Kristus jauh lebih mulia dari segalanya. (Pilipi 3:7-11). Murid akan melihat kesejatian hidup seorang guru, bukan hanya dapat mengatakan, mengajarkan dan menceramahkan, namun menjalani dalam keseharian sebagai guru Kristen. Mereka melihat dan merasakan betapa sukacita menjadi guru mereka.

\section{KESIMPULAN}

Dalam penelitian ini yang berjudul "Kompetensi Kepribadian Guru Pendidikan Agama Kristen Dalam Meningkatkan Kecerdasan Spiritual di Tingkat Sekolah Menengah Pertama" penulis telah membahas dan menguraikan secara singkat yang berkaitan tentang pokok - pokok pembahasan tersebut. Kompetensi kepribadian guru pendidikan agama kristen merupakan kompetensi terpenting secara khusus dalam peningkatan kecerdasan spiritual peserta didik. Guru memiliki tanggung jawab membimbing dan mengajar peserta didik dengan tujuan belajar mengenal, memahami dan menghadapi seluruh aspek kehidupan. Guru yang menjadi jembatan dan sekaligus ujung tombak yang membawa perubahan dalam meningkatkan kecerdasan spiritual peserta didik memiliki pengetahuan yang

\footnotetext{
${ }^{8}$ Sonya Iman Lestari Lumbantobing, "Guru Agama Kristen Dalam Pembentukan Karakter Kristiani," Kerusso 1, no. 1 (2015). 12
} 
luas dan menjadi sumber daya manusia yang berkualitas yang dapat membangun dirinya sendiri maupun orang lain.

Peserta didik yang menjadi generasi penerus bangsa sudah seharusnya di persiapkan untuk memiliki kecerdasan spiritual yang meningkat dan bertumbuh dan pribadi yang dapat membuat perubahan dan kemajuan yang lebih baik dalam segala aspek kehidupan dimasyarakat luas. Dengan demikian kompetensi kepribadian yang dimilki guru pendidikan agama kristen mempunyai pengaruh besar dan sangat penting untuk memahami dan mengerti serta menerapkannya karena hal itulah yang dapat dilihat dan diteladani oleh setiap peserta didik sehingga dapat meningkatkan kecerdasan spiritual dan terpraktek lewat karakter peserta didik tersebut. Melalui kompetensi yang dimiliki oleh setiap guru PAK maka peserta didik akan dapat melihat dan merasakan bahkan kemampuan guru PAK tersebut akan menjadi teladan bagi setiap peserta didiknya. Maka, guru pendidikan agama kristen melalui kompetensi kepribadiannya dapat meningkatkan dan membawa perubahan bagi peserta didiknya dengan mengajar dengan perhatian dan hidup dalam kasih. Pendidikan agama kristen merupakan pendidikan yang harus memiliki kesaksian firman Tuhan dan kehidupan pendidik itu didasarkan kepada kebenaran firman Tuhan. Seorang guru agama kristen jangan menuntut setiap peserta didik untuk berubah jikalau dari diri seorang guru tersebut tidak ada yang dapat dilihat ataupun tidak ada perubahan dari diri seorang guru tersebut. Sebagai guru agama kristen haruslah memegang penuh prinsip kebenaran firman Tuhan melalui pola pikir kristen yang benar, yaitu harus memiliki kasih seperti Tuhan Yesus dan memiliki perkatan dan pengajaran yang benar. Guru agama kristen bukan menjadi guru yang yang berlebihan seperti jaman sekarang yang disebut lebay, juga guru agama kristen juga bukan guru yang mementingkan diri sendiri dan hanya mencari keuntungan untuk dirinya sendiri dalam mengajar. Tetapi guru agama kristen haruslah menjadi guru yang dapat diteladani dan di contoh oleh setiap peserta didiknya dan harus mengajar tentang jalan kebenaran. Menjadi pengajar agama kristen adalah panggilan Tuhan yang istimewa bagi setiap pendidik kristen, maka untuk itu seorang guru agama kristen sangat perlu terus menerus menyerahkan dirinya kepada Allah untuk diurapi menjadi berkat untuk anak didik

\section{KEPUSTAKAAN}

Antonius. Buku Pedoman Guru. Bandung: Yrama Widya, 2014. Asteria, Prima Vidya. Membangun Kecerdasan Spiritual Anak Melalui Pembelajaran Membaca Sastra. Malang: UB Press, 2014. 
Dwi Hastuti. Model Harmonisasi Peran Keluarga Membentuk Karakter Anak. Bogor: TP, 2014.

Lumbantobing, Sonya Iman Lestari. "Guru Agama Kristen Dalam

Pembentukan Karakter Kristiani." Kerusso 1, no. 1 (2015).

Mulyasa, E. Standar Kompetensi Dan Sertifikasi Guru. Bandung: Remaja Rosdakarya, 2007.

Nurtanto, Muhammad. "MENGEMBANGKAN KOMPETENSI

PROFESIONALISME GURU DALAM MENYIAPKAN

PEMBELAJARAN YANG BERMUTU." In Inovasi Pembelajaran Berbasis Karakter Dalam Menghadapi Masyarakat Ekonomi ASEAN, 2016.

Rube, Tasha. "Cara Memiliki Keberanian." WikiHow.

Tafonao, Talizaro. "Peran Guru Agama Kristen Dalam Membangun Karakter Siswa Di Era Digital." BIJAK 2, no. 1 (2018): 1-214. 